\title{
High-Skilled vs. Low-Skilled Migrant Women: the Use of Competencies and Knowledge-Theoretical and Political Implications: an Example of the Elderly Care Sector in Poland
}

\author{
Sabina Kubiciel-Lodzińska ${ }^{1}$ (D) - Jolanta Maj ${ }^{1}$ (D)
}

Accepted: 19 February 2021 / Published online: 24 March 2021

(C) The Author(s) 2021

\begin{abstract}
This paper presents the influx of migrants into the elderly care sector in Poland, which, until recently, has been perceived as a country that "exports" caregivers. It describes the results of 31 individual in-depth interviews conducted with immigrant women who take care of elderly in Poland. The purpose of the study was to determine the profile of an immigrant taking up work in the elderly care sector, including the specification of their education level and competencies. It was determined that $55 \%$ of the respondents have higher education, including over $20 \%$ with a degree in nursing or physiotherapeutic education. It was established that, when analysing migrants in the care sector, it seems necessary not to divide migrants based on their education level (high- vs. low-skilled), but rather to consider the education profile as a whole (general and special profile education). Women with specialised education differ from the other migrants in regard to their better labour market position (higher remuneration, legal employment) and the scope of skill usage. The comparison of high-skilled and low-skilled workers in the care sector is very useful from the perspective of policymakers due to the fact that there is an issue of over-qualification in Poland. The article contributes to the literature, especially research dealing with brain waste, as there is theoretical and empirical gap in research on the differences between high-skilled and low-skilled migrants working in elderly care.
\end{abstract}

Keywords High-skilled migrant women · Low-skilled migrant women · Nurse $\cdot$ Brain waste $\cdot$ Migration policy

Sabina Kubiciel-Lodzińska

s.kubiciel-lodzinska@po.edu.pl

1 Faculty of Economics and Management, Opole University of Technology, 76 Prószkowska Street, 45-758 Opole, Poland 


\section{Introduction}

Poland is currently one of the leading migration destination countries in Europe. In 2018, the highest number of first-time residence permits for third-country members was issued (Eurostat, 2019). It is no longer only a country of emigration, but its significance as an appealing country for immigrants is increasing, especially for immigrants from outside the EU (Solga \& Kubiciel-Lodzinska, 2017). For years, Poland has been perceived rather as a care-labour-exporting country (Goździak, 2016; Leiber et al., 2019), but this is changing. In particular, elderly care is an increasingly important area of the influx of the foreign workforce. Currently, Poland is both a sending and receiving country, which makes it an extremely interesting case (Palenga-Möllenbeck, 2013). The rise in the share of elderly people in Poland is accelerating. By 2050, the share of people aged 65 and above will exceed $32 \%$ (in 2018 it was 18\%) (Heffner et al., 2019). When focusing on the experiences of other countries, it can be assumed that immigrants will be a progressively crucial group from which care workers will be recruited. For example, in Australia approx. 35\% (Negin et al., 2016) and in Italy over $70 \%$ (Gallo \& Scrinzi, 2016) of elderly caregivers are migrants. The surge in labour demand for migrants in elderly care is also visible in Central and Eastern Europe, i.e. the Czech Republic (Ezzeddine, 2014) and Hungary (Szeman, 2012). Furthermore, these caregivers are mostly female migrants (Schwiter et al., 2018; England \& Dyck, 2011; Huang et al., 2012). The influx of migrants in this sector is an area worthy of exploration, as working in the household services sector has been deemed unappealing (dead-end job) due to the lack of opportunities for occupational development. It may often lead to the feeling of loss of competencies (deskilling) if such employment is undertaken by those with higher education (Triandafyllidou, 2016). There are two dominant barriers to the transferability of skills of high-skilled immigrants: language differences and occupational licensing (Chiswick, 2011). Work in an elderly care sector is usually associated with unqualified personnel. This study features an effort to determine the profile of immigrant women taking up work in this sector in Poland. For the purpose of this research, it has been assumed that high-skilled workers are defined as those who hold a university degree (Iredale, 2016), while workers with a secondary and lower education level, or who are still studying, were included in the low-skilled category. Work in an elderly care sector is usually associated with unqualified personnel.

Studies on the role of the foreign workforce in elderly care in Poland are sparse (Sobiesiak-Penszko, 2015; Kubiciel-Lodzińska, 2019). Analyses conducted so far have featured the home services sector (Kindler et al., 2016), but care services dedicated to the elderly are only now becoming a subject of studies and focus mainly on the demand side (Kałuża-Kopias, 2018). Most of research on immigrants has been done on unskilled individuals in typical secondary sectors. However, the new wave of immigration from 2015 onwards is much more heterogenous, with more and more semiskilled and high-skilled individuals arriving in Poland. Specifically, the presence of high-skilled migrant women (HSMW) in the elderly care sector in Poland has not yet been analysed.

We were interested in contributing to the literature on migrant care workers and their motivations for migrating. The aim of the article is to find the relationship between the level of education and professional experience and the situation of migrant women in 
the care sector in Poland. The goal of this paper is to determine to what degree education level and professional experience resulting from it influence the situation of migrant women in the care sector in Poland.

The following research questions have been asked: (1) How do the differences in education influence the motives for taking up employment in elderly care among immigrant women in Poland and their work status? (2) How does the education, especially of women with specialised (medical) education, comparing with lowskilled women influence behaviour, expectations and plans of HSMW?

The article contributes to the existing literature, as there is theoretical and empirical gap in research on the differences between high-skilled and low-skilled migrant women working in elderly care. Also, it contributes to the existing knowledge by demonstrating that not all HSMW are the same and that there should be a distinction between "specialists" and "generalists" in medical/nursing studies. This is a universal issue, as high-skilled migration, including migrants with specific, desirable qualifications, is of global nature.

The structure of the paper is as follows. The second section features a review of the literature on the elderly services sector. The third section presents the research design and study sample, and the study results are discussed in the subsequent part. Lastly, the paper ends with a conclusion and discussion section, which includes recommendations as well.

\section{Literature Review}

At present, an increasingly large share of the international migration flow is made up of high-skilled migrants. Skills, as a term, are defined in various ways. In most cases, it is related to the highest level of education obtained by the migrant. Such an approach is sometimes criticised due to the certain prestige of schools or universities, and thus a different level of knowledge, skills and competencies obtained (Boucher, 2019). Despite those concerns, the term "high-skilled" is identified with a tertiary education, among others, by the World Bank or OECD (Docquier \& Marfouk, 2006). Consequently the term "low-skilled" is assigned to those with no education, or with a primary (Brunello et al., 2017) or a lower-secondary education (Biffl, 2012).

Research shows that high-skilled migrants very often undertake employment in jobs below their qualifications (Borjas, 1991, 1994; Baker \& Benjamin, 1994). Such a situation is defined as brain waste, which occurs when a person who has incurred education costs does not benefit from the raised capital (Pires, 2015). Brain waste results from the fact that skills, qualifications and professional experience are not used in the incoming country (Chammartin, 2008). It occurs in two cases: illegal work (Hanson, 2006) or low international transferability of human capital (Chiswick \& Miller, 2009b). The second situation occurs when the migrant has to apply for the recognition of their diploma (hence their qualification) from their home country (Yu, 2019), but it may also result from, among others, a different scope of professional experience (Ferrer \& Riddell, 2008) or the lack of professional networks (Batalova \& Fix, 2015). Difficulties in entering the labour market may also result from officially unnamed prejudices against migrants, the so-called skill discounting (Reitz, 2001).

In terms of not fully using qualifications by highly qualified migrants, the term "deskilling" is also used, which means that migrants undertake employment not fitting 
their qualifications and professional experience. Difficulties with the recognition and transfer of skills and qualifications, resulting from a higher education, are not uncommon (Brzozowski, 2008). This may also affect migrants in Poland. However, the brain waste phenomenon is almost completely unresearched in the Polish literature. Research conducted so far has focused mostly on migrant entrepreneurship of women from former USSR countries (Andrejuk, 2015, 2017) as well as carrier paths of specialists from Eastern countries (Dolińska, 2019).

A major sector which attracts migrant workers is the care sector and, in particular, elderly care. An influx of immigrant workers is especially visible in developed countries, in which a "care crisis", meaning the inability to meet the demand with native caregivers, has been observed (Yeates, 2010). Native workers are not interested in work in this sector due to the perceived low status (Goel \& Penman, 2015) and undesirability of this type of work (Hugo, 2009). Therefore, mostly immigrants undertake work in the care sector. Care work is often referred to as the three C'scooking, cleaning and caring (Anderson, 2000)_comprising two areas: looking after (cooking, cleaning, nursing) and caring for (emotional support) (Fraser, 1995). Caregivers may offer services including formal healthcare (measuring blood pressure and sugar levels) and informal care (like cleaning). The scope of services depends on the patients' needs and on the caregiver's qualifications (Salami et al., 2017). This particular sector attracts unqualified as well as high-skilled migrants including nurses and physiotherapists (Stilwell et al., 2004). Brain waste of medical professions among immigrants occurs quite frequently, as shown by research conducted on physiotherapists in Canada, for whom the main barrier for working in their learned profession was of legal nature (Lofters et al., 2014). It has also been shown that doctors in Ireland (Humphries et al., 2013) and nurses from African countries in Great Britain have suffered discrimination and felt that their experience was not valued, leading to a feeling that their competences as nurses were in question (Likupe, 2006). In Poland, the main problem for migrants from the so-called third-world countries with a medical degree is the lack of recognition of their qualifications and differences in the education system. Many nurses living in socialist countries before 1989 have earned postsecondary diplomas from vocational schools. Although in reality they are trained nurses, many of them cannot work legally in the EU, as European regulations require tertiary education for being a nurse. This problem has already been visible with Polish nurses working in the houses of elderly in Germany or Italy (Knaebel, 2015).

On the whole, most workers in the care sector are women (Lovelock \& Martin, 2016). HSMW are doubly disadvantaged due to their gender and nationality, which increases their deskilling in relation to native women and migrant men. According to the literature, migrant women are more likely to have qualifications in education and medical sectors where the transfer of skills can be problematic (Larsen et al., 2005). They are, for example, disproportionately present in cleaning and caring and refer to each other as the "BBC", which means "British Bottom Cleaners" (McGregor, 2007), which has an unambiguous negative overtone.

Despite the fact that work in the care sector is deemed low-skilled, immigrants that conduct such work are not always uneducated (Bettio et al., 2006). Among elderly caregivers, medical staff and, specifically, nurses constitute a special group. In the latter case, a particular barrier to entry is the difficulty connected with the recognition of qualifications. This results in a situation where, in order to avoid a complicated 
procedure of diploma recognition, they decide to take up employment below their qualifications, mostly in the care sector, as they typically have the necessary experience from their home countries (Groutsis, 2009). Some countries, like Canada, have introduced certain facilitators in order to attract immigrants with a medical education and working in care services. Thus, over $40 \%$ of migrant caregivers have medical qualifications from their home countries (Bourgeault et al., 2011). Sometimes the HSMW, even with their qualifications recognised, are pushed into the care service, as they do not feel accepted by their native co-workers (Hawthorne, 2001). As the example of Japan shows, despite having a formal legal agreement on the acceptance of Indonesian nurses, they were more often hired to perform activities related to washing, feeding the patient, cleaning or ordering medical tools rather than performing strict medical activities (Okushima, 2010; Yagi et al., 2014). This led to a "lose-lose" situation in both countries, as the medical staff was not able to make use of their full potential (Yagi et al., 2014). On the other hand, elderly care does not always necessarily require medical qualifications. Some research has shown that honesty, patience and devotion, especially when medical skills require additional remuneration, are sometimes more important than medical skills (Bettio et al., 2006). Thus, specialists (immigrants with education, practical skills and experience in elderly care) and generalists (immigrants without education, practical skills and experience in elderly) care have been distinguished (Harrold et al., 1999). It is similar in Poland where the number of older people requiring care, which used to be provided by family members, is growing rapidly (Szweda-Lewandowska \& Kałuża-Kopias, 2019).

Working in the care sector may be perceived by nurses and medical staff as a substitute for employment in their learned professions. It is primarily a way of earning more than in the home country and thus constitutes an opportunity to help loved ones who remain in their home country (Salami et al., 2014). However, as noted by Pylypa (2013), the migration of health professionals has substantial implications for human resources in the source and recipient countries. Although, as to the best knowledge of the authors, the issue of career plans of HSMW in the care sector has not been subject to analysis, research has shown that this group had a higher inclination to go back to their home countries than other groups (Thomas-Hope, 2002). The presence of students (of nursing, among others) in the elderly care sector is a noteworthy phenomenon. This is a group often employed, among others, by retirement homes in Great Britain. Some retirement homes give part-time agreements to social care students who use labour market incentives provided by their student visa (Cangiano et al., 2009).

The research was conducted in the spirit of the grounded theory. Furthermore, in the article, we analysed a mix of motivates, which we understand as complex objectives, rationalisations and perceived consequences which often fall into one migration trajectory. The conducted literature review showed that the migration motives include not only economic but also non-economic objectives. In order to include a broader context, we used Bygnes and Erdal's work (2017) and framed motivation within a "working life" context, which included among others the nature of work (legal and illegal), salaries and strivings to conciliate family life and work.

The conducted literature review showed a theoretical and empirical gap, as there is no research on differences between high-skilled and low-skilled migrants working in elderly care. The literature review did not show any theoretical approaches or analyses comparing behaviour, expectations or plans of HSMW, especially those with 
specialised (medical) educations, with low-skilled women. The brain waste phenomenon among nurses and other medical staff is all the more important, as Poland and other countries face a high demand of caregivers, which cannot be satisfied with the native workforce. In short, failing to make use of their skills is a waste of human capital.

\section{Research Methodology and Design}

This study features a reference to the grounded theory (Glaser et al., 1968). The basis for presenting the collected material is a narrative analysis. The paper is based on the analysis of empirical material collected in a qualitative study. Thirty-one face-to-face in-depth interviews (IDIs) were conducted among migrant women working as elderly caregivers in Poland. In our study, they were defined as women who take care of elderly persons and of their household on a permanent basis (they live with the dependent person) or periodically, e.g. several hours a day or several times a week. The definition was developed based on analysis from O'Rourke and Tuokko (2003) and Van Durme et al. (2012).

Two sampling methods were used in the study: snowball sampling and respondentdriven sampling (Heckathorn, 1997). A semi-structured questionnaire was used. It should be emphasised that there was no criteria regarding the education level or type (general or specialised) for the sample selection. The IDIs were conducted in Polish, and all the respondents were able to communicate in the chosen language. The vast majority of respondents were immigrants from Ukraine (28 respondents), two from Belarus and one from Russia. The youngest person in the group was 18 years old and the oldest 57 years old. As many as 17 individuals had higher education, including 7 women who declared graduating from nursing or physiotherapy studies (special profile education). The others (14 respondents) were qualified to the low-skilled segment; however, only 2 had a vocational education and 12 graduated from high school (secondary education). A higher number of high-skilled women have been working legally (9 persons) than low-skilled (4 persons). Most women (ca. $60 \%$ ) worked illegally, which confirms that employment in the home services sector, including employment related to care, is usually illegal (Van Hooren, 2010). The details of the respondents were presented in Table 1 .

The approach in data analysis was driven by the interest in potential differences between high- and low-skilled women. However, during the analysis, differences within the HSMW group became visible. Thus, the category of high-skilled migrants was divided into those having a special profile education (nursing, physiotherapy) and other general (higher) education. MAXQDA software was used for the analysis. The data was analysed using open and axial coding (Strauss \& Corbin, 1994, 1997; Charmaz, 2006). To ensure the quality of the analysis, the audit trial, collaboration and disconfirming evidence validity procedures were used (Creswell \& Miller, 2000). Additionally, in order to ensure validity and reliability during the analysis, we searched for alternative explanations as well as negative cases (Brink, 1993; Rose \& Johnson, 2020). We attempted to follow the steps suggested by Strauss and Corbin $(1994,1997)$. Firstly, a mind map was developed based on line-to-line coding, which enabled the development of the first- and second-order categories and finally the aggregated themes. The structure of the coding and themes was presented on Fig. 1. 
Table 1 Structure of the sample

\begin{tabular}{|c|c|c|c|c|c|}
\hline Code & Age & Education & Profile & Employment & Way of providing work \\
\hline R 2 & 49 & High-skilled & Generalist & Illegal employment & Living in \\
\hline R 5 & 28 & High-skilled & Generalist & Illegal employment & Living in \\
\hline R 6 & 20 & Low-skilled & Generalist & Illegal employment & Living out \\
\hline R 7 & 44 & High-skilled & Specialist & Legal employment & Living in \\
\hline R 8 & 21 & Low-skilled & Generalist & Illegal employment & Living out \\
\hline R 10 & 22 & Low-skilled & Generalist & Illegal employment & Living out \\
\hline R 11 & 57 & Low-skilled & Generalist & Illegal employment & Living in \\
\hline $\mathrm{R} 12$ & 43 & Low-skilled & Generalist & Illegal employment & Living out \\
\hline R 14 & 27 & Low-skilled & Generalist & Legal employment & Living out \\
\hline R 16 & 39 & Low-skilled & Generalist & Legal employment & Living out \\
\hline R 17 & 26 & High-skilled & Specialist & Legal employment & Living in \\
\hline R 19 & 24 & High-skilled & Specialist & Legal employment & Living in \\
\hline R 20 & 24 & High-skilled & Generalist & Legal employment & Living out \\
\hline R 21 & 34 & High-skilled & Specialist & Legal employment & Living out \\
\hline R 22 & 34 & Low-skilled & Generalist & Illegal employment & Living out \\
\hline R 24 & 27 & High-skilled & Specialist & Illegal employment & Living out \\
\hline R 25 & 37 & Low-skilled & Generalist & Illegal employment & Living out \\
\hline R 26 & 25 & Low-skilled & Generalist & Legal employment & Living in \\
\hline R 27 & 18 & Low-skilled & Generalist & Illegal employment & Living out \\
\hline R 28 & 58 & Low-skilled & Generalist & Illegal employment & Living out \\
\hline R 30 & 30 & High-skilled & Generalist & Illegal employment & Living out \\
\hline R 31 & 18 & Low-skilled & Generalist & Illegal employment & Living out \\
\hline R 32 & 20 & Low-skilled & Generalist & Legal employment & Living out \\
\hline R 33 & 49 & High-skilled & Specialist & Legal employment & Living in \\
\hline R 34 & 34 & High-skilled & Generalist & Legal employment & Living in \\
\hline R 36 & 41 & High-skilled & Generalist & Legal employment & Living in \\
\hline R 38 & 25 & High-skilled & Generalist & Illegal employment & Living out \\
\hline R 39 & 27 & High-skilled & Generalist & Illegal employment & Living in \\
\hline R 40 & 34 & High-skilled & Generalist & Illegal employment & Living out \\
\hline R 41 & 30 & High-skilled & Generalist & Illegal employment & Living out \\
\hline R 42 & 36 & High-skilled & Specialist & Legal employment & Living in \\
\hline
\end{tabular}

Source: Own elaboration

The identification of the aggregated themes led also to the identification of the subsections in the following part of the paper. We chose a process approach showing how migrant women characteristics translate into motives for taking up employment in the care sector, which translate into a different work status for the women. Finally the work status of the women translated into different plans (professional and migrational) for the migrant women. The selection of the topics was a result of the conducted analysis.

The quotations for the paper were chosen first separately by the individual authors and then discussed in a common session during which the final selection was made. 


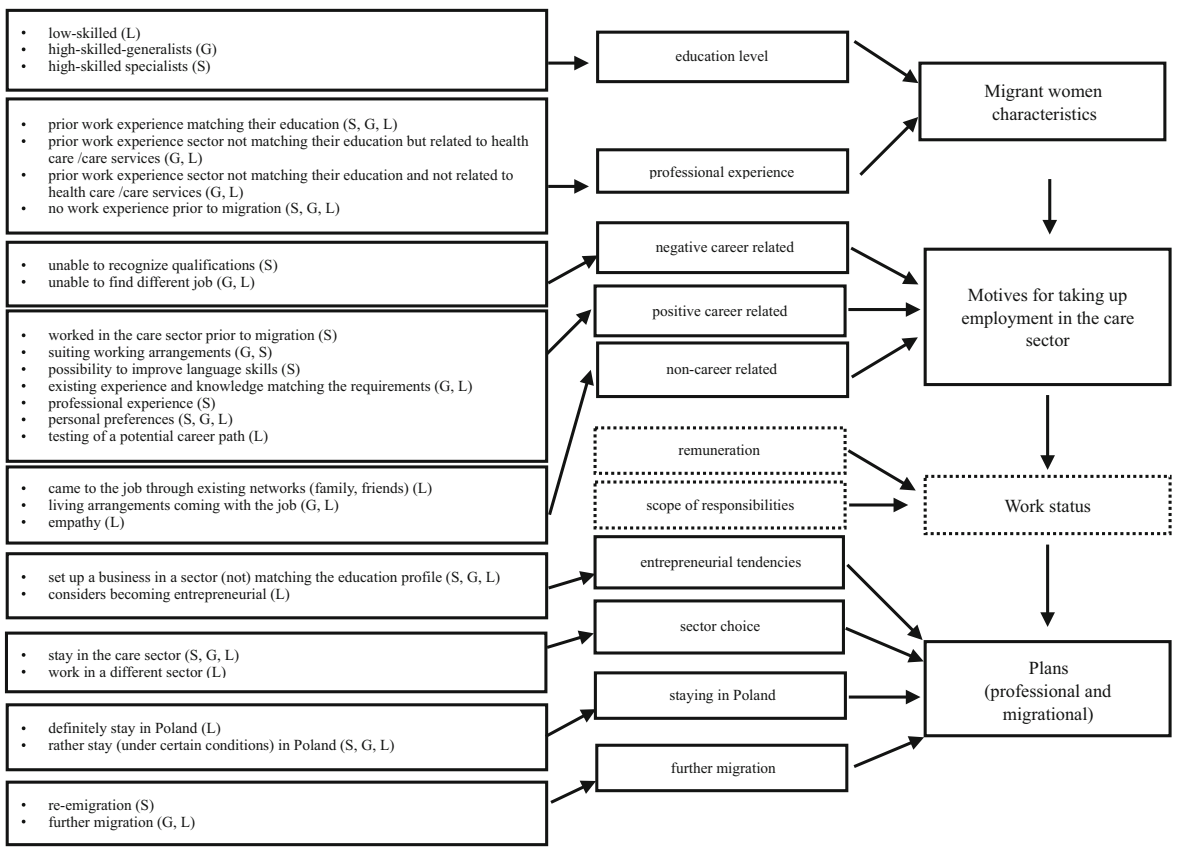

this categories were not subject to typical coding as they were results from structured questions with a possibility to elaborate

Fig. 1 Research results and coding scheme. These categories were not subject to typical coding as they were results from structured questions with a possibility to elaborate

\section{Research Results}

\section{Migrant Women Characteristics}

In order to answer the first research question, we analysed the obtained data to find the differences in education among migrant women working in the care sector in Poland. The structure of the sample due to the level and character of education (specialists and generalists) was already presented. However, to fully understand the characteristics of the migrant women working in elderly care, we also included information on professional background, as significant differences in this field emerged. Among high-skilled women migrants, the majority had previous work experience. Only one high-skilled, special profile educated respondent (R21) did not have any previous work experience. High-skilled women (specialised) worked in hospitals as nurses and physiotherapists or in the care sector. The length of the previous professional experience varied from 1 to 28 years. Respondent no. 17 stated that she was not satisfied with working in a hospital:

I worked in a hospital as a nurse, but I did not like it that much because I had no free time. The ball rang and you had to go to the hospital, because something changed, because there was no schedule. It was not organised. I had a lot of night shifts and I did not get extra money for them. (R17, high-skilled, specialist)

Two respondents had no previous work experience among the high-skilled, generally educated migrant women. R38 stated that she moved to Poland right after graduation. 
Other migrant women had previous work experience mostly in their obtained professions, compatible with their education and only one (R36) in the care sector. In this case, their work in the care sector was, essentially, additional work. The main employment was compatible with the obtained education (accounting).

In regard to the low-skilled migrant women, four groups could be distinguished. The first group was made up of women who did not have work experience prior to coming to Poland. The majority of them came to Poland to study, so they were too young to take up employment in their home countries.

No, I did not work. I only had a secondary education and I left straight to Poland to study. (R10, low-skilled)

[after coming to Poland] I worked in a restaurant as a waitress. I liked the job because I could speak to people and learn Polish. It helped me with my work and at the University, as I could learn the language and communicate with others. (R6, low-skilled)

The second group included women who had previous work experience, but, however, did not work in with the field of their learned profession. They worked as cleaners, beauticians, saleswomen or warehouse employees.

The third group included women working in their obtained profession.

I have two learned professions. (...) I used to work in a kitchen as a cook and before that, in Soviet times, in the beginning, I used to work where there were sprayers - field cultivating machines, sprayers, I worked on such a large one (...) I worked in a kitchen as a cook for a long time and then I worked in this factory where these sprayers were made. I operated a gantry crane. (R11, low-skilled)

The fourth group included women caring for the elderly without a professional or specialised education.

Already in regard to professional experience, a distinction between the specialists and the other groups may be detected. Specialists were among those who had prior work experience matching their education (in this case health or care services) or among those who had no work experience prior to migration. Hence, if they had been working prior to migration, it was only in their education field, making them the most qualified caregivers or caregivers with high-profile specialisation.

\section{Motives for Taking Up Employment in the Care Sector}

The various characteristics of migrant women including different education level, scope, as well as different professional experience of women translate into a variety of motives for taking up employment in the care sector. Consequently, this leads to a contrasting situation in the country of immigration, which is included in the second research question.

Those with a higher education who work as elderly caregivers are exposed to a depreciation of qualifications and, in turn, brain waste. As indicated by Cuban (2016), McGregor (2007) and Anderson (2000), working in the care sector is perceived as "dirty work", and thus as something depreciating value, also to due to the large 
proportion of the $2 \mathrm{Cs}$, meaning cooking and cleaning (Anderson, 2000). However, when analysing the case of migrant women in the care sector in Poland, a disparate picture emerges.

Firstly, in the narratives of the respondents, the threat of the lack of use of qualifications did not appear. The respondents coming to Poland were aware of the fact that they would undertake work outside as well as below their level of education. In many statements, they emphasised how important it was for them to help someone and respond to someone's specific needs. Therefore, although they were prepared to work below their qualifications, HSMW did not present a negative attitude towards said work. Employment in informal elderly care is characterised by a low barrier to entry and enables migrants to find work quite easily (Spencer, 2010). However, this often means the depreciation of qualifications for those with professional qualifications. On the other hand, it is similar to the learned profession and may give them the feeling that they are making use of their qualifications.

As for the migration motive, the respondents, regardless of their education level, indicated the improvement of their economic status or, in case of the students, their willingness to continue their education at a Polish university.

While analysing the motives for taking up employment, we distinguished the positive and negative career-related motives as well as non-career-related ones. Based on the conducted analysis, it was found that among the HSMW, the career-related motives for choosing a job occurred more frequently. In particular, HSMW mentioned the positive career motives. The high-skilled generalists mentioned the financial aspect, flexible working hours (also mentioned the specialists) and the fact that they already have the knowledge on how to care for the elderly. Low-skilled migrant women indicated the professional experience they already had and the idea that the job was an opportunity to check if it would be a suitable future profession for them (students). Among all the groups, the motive of simply enjoying the job and taking care of others was also mentioned.

I've always looked after children. I feel good doing it (...) this work is similar. As I always worked with children, took are after them and the opportunity to migrate presented itself I took it. (R2, high-skilled)

However, only the specialists mentioned their previous work experience strictly in the care sector as well as their professional experience. They also perceived this kind of employment as an opportunity to improve their language skills.

Within the negative career-related motives, the lack of recognition of their profession in Poland was especially visible among the specialists.

I could not find a job in my profession, and I wanted to work in a hospital. It was not always appreciated that I had education and experience in Ukraine. In order to work in a hospital, I would have to finish my studies here, and that's how I started to work with the elderly. For me it is something similar. I can say that I am a private doctor. (R17, high-skilled, specialist)

The second negative career-related motive was the fact that the women were not able to find work in their professions. This motive was mentioned by the generally educated women, both low-skilled and high-skilled. 
Within the non-career related motives, we included the paths taken to the profession of elderly care and other motives for taking up this type of job (non-career-related). Analysing the ways in which respondents came to the job, we can observe that those are mostly through networks. In general, most respondents found their current jobs through family and/or friends. Those were motives pointed out by low-skilled migrants. High-skilled migrants looked for a job in the care sector mostly deliberately. Analysing the non-career-related motives, low-skilled workers pointed to empathy as a motive:

I feel sorry for those people. I know they need help and it can be very different... It is difficult for them... (R28, low-skilled)

Also, in both groups (low-skilled and high-skilled general education), the respondents mentioned that one of the reasons for taking up the job was the fact that it came with a flat, so they did not have to worry about living arrangements.

\section{Work Status}

The migrant women's characteristics and their motives for taking up employment in the care sector translate into a different work status for the women. Under work status, we summarised the scope of responsibilities of women as well as their remuneration. The questions about work status were close-ended with the option to elaborate; thus they were not subject of the multi-step coding.

Through analysis of the responsibilities, it was noted that although some duties were similar to all the analysed groups, there were responsibilities which were only performed by the specialists, which included giving injections, massages and physiotherapy and applying dressings. There were, however, also examples of low-skilled respondents who had similar responsibilities (two women with previous experience in elderly care).

As Respondent no. 17 explained:

I am a professional nurse and this is what I do. I can give shots, I can give medication, I can also examine the patient and this is why I was chosen. The person [I am taking care of] is older and has health issues, as it happens with people of this age. My employers were looking for someone who is a nurse, because something can suddenly happen to an older person and then I can give shots or give medication. (R17, high-skilled, specialist)

In the analysed cases, there was, however, a set of similar responsibilities, which included first and foremost cleaning, cooking, doing laundry, shopping, leisure time management, hygiene maintenance, assistance in getting dressed, solving official matters and going to the pharmacy. While, as mentioned, the special profile educated women were able to give medication and administer injections, the responsibilities of the low-skilled migrants included reminders about taking the proper medication. Even the student respondents stated themselves:

I can remind him that he has to take some medication, however I cannot give them to him because I do not have the education yet. (R32, low-skilled) 
No, I don't do that [give shots, do massages]. If the lady I am taking care of forgets to take her medication, I remind her to do that. I don't give any shots. (R31, low-skilled)

The respondent groups also differ in regard to their attitude towards such medical responsibilities. The statements of generally educated high-skilled and low-skilled migrants show fear and reluctance in performing these types of responsibilities. Overall, the respondents emphasised that they do not conduct such services due to the lack of necessary qualifications and or simply being afraid to do them if asked. "I don't do it [give shots]. Specialists do it" (R2,high-skilled, generalist). "No, no, I don't have such responsibilities [giving injections and medication] because I am not a doctor and I am afraid to do it" (R10, low-skilled).

The rather broader scope of responsibilities of the special profile educated highskilled women also becomes visible when analysing the working hours - they tend to work more hours than the other groups and they more often describe their working arrangements as $24 / 7$ work.

Respondent no. 17 stated: "My contract states 40 hours a week, however I live there so you can say 24/7. But I don't mind" (R17, high-skilled, specialist). The other groups, high-skilled generalists and low-skilled migrant women, worked fewer hours. With individual exceptions, they work from several hours a day to $8 \mathrm{~h}$ a day. The amount of working time may thus be connected with the scope and complexity of the responsibilities.

Also during the study, it was determined that the specialists usually worked legally. This was related to the fact that the elderly persons' families sought caregivers with competencies in providing medical care due to the health condition of their relatives.

The various backgrounds of the migrant women as well as their scope of responsibilities also translate to a different level of compensation. Special profile educated highskilled women receive the highest remuneration (a monthly average of 2333 PLN), followed by general educated high-skilled women (a monthly average of 1956 PLN). Low-skilled women received the lowest pay (a monthly average of 1390 PLN).

It should also be emphasised that the level of pay also depends on the scope of responsibilities, the working hours and the nature of the employment. It shows that in terms of remuneration, and thus social status of the caregivers, a difference between the analysed groups exists.

\section{Professional and Migrational Plans}

As previously indicated, the distinct characteristics of the migrant women translate into a variety of motives for taking up employment in the care sector but also into different work status. Furthermore, they lead to a disparity in remuneration. In addition, as the analysis has shown, all of them translate into different plans (professional and migrational) for the migrant women.

The analysis has shown that, in general, the specialists plan to go back to their home countries unconditionally or with certain conditions, which in the case of the respondents were the situation in Ukraine, the necessity to earn and save some money or the lack of possibility to bring their family to Poland. However, the dominant statement was that they simply want to go back. Despite this, a majority of the respondents plan to 
stay in Poland, but a significant group was not absolutely convinced as of yet. A small group (low-skilled and generalists) stated that they would like to emigrate further, indicating West European countries as the next possible destination, making Poland a stopping point in their migration journey. The migration plans show that although the specialists have a better social situation and work status, they declare intentions to go back to their home countries rather than stay in Poland or emigrate further.

In regard to professional plans, the following conclusions were drawn. The first group of respondents, coming from all analysed migrant groups, are women who would like to set up their own business. Low- and high-skilled migrant women declared their willingness to set up a business in fields not connected to their education profile. This group also included specialists. Low-skilled women also considered setting up businesses connected to their education (professional experience). Additionally, some lowskilled women were considering becoming entrepreneurs after working a few years in the care sector, which would allow them to save the necessary financial capital. The majority of migrant women would, however, like to continue their work in the care sector. High-skilled women declared their willingness to work in the care sector due to the perceived creativity of the job, the fact that working in care sector is satisfying and not monotonous, and also the stability the job offers.

I am a person for whom it would be difficult to work on production line, stand somewhere monotonously. I feel better in this sector, more creative. (R2, highskilled)

One low-skilled woman (a nursing student) stated that she would definitely like to keep working in the care sector as this is the profession she is currently learning. Women declaring that they would rather like to stay in the care sector argued that they took on a responsibility they would not like to abandon (high-skilled, special profile educated). They also indicated the stability the job offers but also would like to keep working in the care sector as additional employment. Only low-skilled migrants declared that they would definitely like to work in a different sector, as they perceive working in the elderly care as too hard and difficult or simply came to this job circumstantially.

\section{Discussion}

Employment in the personal services sector increases in the European Union (Abrantes, 2012, p. 231). This results from the ageing population (Börsch-Supan, 2013, p. 398), causing an increase in demand for care services, the coverage of which is a big challenge to the insufficient number of native-born caregivers. More attention is being paid to the transformation of the model of elderly care from the family model to the migrant in the family (Bettio et al., 2006). The topic in on relevance not only for Poland, but also other countries.

It is important to note that in the analysed sample, almost half of the respondents had higher education. Moreover, $1 / 4$ of them had a specialised education (nurses and physiotherapists). For comparison, Gordolan and Lalani (2009) found that $30 \%$ of the respondents employed in elderly care in Great Britain declared participating in some eldercare training, which in most cases were short, 1-day or 1-week courses. Thus, the 
responsibilities, which in the UK are handled by low-skilled caregivers in Poland, are being handled by highly (over)qualified women. In the Polish study, it was found that specialists - people with an education in nursing or physiotherapy usually work legally-receive higher remuneration and have a broader scope of responsibilities. Therefore, their work status in Poland is different than the one of the other groups. Researchers from the USA also confirm the greater inclination towards legal employment of people with a nursing education, as it was determined that illegal employment mainly concerned unqualified persons (Martin et al., 2009). Thus, it has been determined that differences in migrant characteristics influence their situation in the countries of immigration.

It has also been determined that there is a market for high-skilled nurses in the Polish care sector, which were hired not as so-called "Polish Bottom Cleaners" (PBC) workers, but rather as specialists. The specialists emphasised that they have been hired because of their qualification as the condition of their patients required professional care. This shows that there may be a niche for HSMW with medical education and experience, which despite the difficulty in gaining recognition of their qualifications may still be hired in professions which require their particular competencies. Although this situation still qualifies as brain waste, these jobs should not be qualified as only "dirty work" or PBC work.

The conducted research also demonstrated that migrants differ in terms of their motives for taking up employment in the elderly care. High-skilled specialists indicated career-related motives: negative motives like the lack of possibility to get their qualifications recognised and positive motives like prior professional experience in the field. On the whole, the "deskilling" phenomenon is quite common in the elderly care sector. This, however, may be accepted by workers in order to earn money (Colic-Peisker \& Tilbury, 2006). In the case of high-skilled generalists and low-skilled migrants, it was mostly due to the fact that they were unable to find other employment. Researchers in Italy have come to similar conclusions (Salaris \& Tedesco, 2019).

For migrants, finding employment in elderly care was seen as an opportunity to gain a foothold in the labour market, either temporarily or as a stepping stone to other opportunities. Researchers from Great Britain have made similar assertions as a result of their research (Hussein et al., 2010). High-skilled specialists more often pointed towards positive career-related motives for working in the elderly care sector, previous work experience, in particular work experience in elderly care or the possibility to improve language skills. Transnational capital and employment experience can be used to change jobs, employment modes or countries (Bruquetas-Callejo, 2019). It is also worth noting that the specialists were the only group willing to re-emigrate to their home countries.

The presented results indicated significant differences between high-skilled and lowskilled migrant women due to the use of their competencies. However, it is important to note that analysing migrant women, especially in the care sector, should be done not only considering the differences between high- and low-skilled migrants, but even more so in terms of the division into generalists and specialists. This may be an important methodological implication. Within the care sector, it seems necessary not to divide migrants only based on their education level (high- vs. low-skilled) but also based on the profile of the education (specialised and general education). The specialists differ from the other migrants in regard to, for example, their work status (higher 
remuneration, legal employment) or the scope of skill usage. In regard to this group, taking up employment in the care sector results from the willingness to even partially work in their learned profession, while for the other groups (generally educated highskilled, so-called "generalists" and low-skilled), employment in the care sector is rather circumstantial. Thus, when analysing work in the care sector, we propose dividing high-skilled migrants into two groups: "generalists" (generally educated, high-skilled) and "specialists" (special profile-educated, high-skilled migrants).

Considering the costs of brain waste, the migrant may decide to go back (if the perceived brain waste is too high) or stay (if the brain waste is acceptable), which may be an indication on why the high-skilled, special profile educated women declared that they would like to go back. The "step-stone" migration policy for international students proposed by Lo et al. (2019) may be a solution to the brain waste problem. In our study, we put students into the low-skilled category, yet the analysis showed differences in their approach to the labour market. Essentially, they would like to work in professions connected to their study fields. They even chose a specific field of study from the point of view of potential future employment. They were also the group with the highest willingness and openness towards entrepreneurship. Mattoo et al. (2008) found that "underplaced" migrants suffer rather from low or poorly transferable skills than from the underutilisation of their skills. This, however, does not apply to the care sector in Poland, where the demand for professional nurses, physiotherapists or even physicians is particularly high. Also, in other sectors, the migrants should be able to utilise their skills and experience, especially the high-skilled ones.

\section{Conclusion}

Current literature focuses on the factors both attracting and pushing migrants into elderly care (Bruquetas-Callejo), their scope of responsibilities (Martin et al., 2009), the changing role of the family (Rugolotto et al., 2017), changes in formal and institutional conditions (Pelzelmayer, 2016; Van Hooren, 2010) and care chains (Palenga-Möllenbeck, 2013). This article contributes to the existing literature by presenting the differences between high-skilled and low-skilled migrant women working in elderly care. It was established that not all HSMW are the same, but that there is a crucial distinction between "specialists" in medical/nursing studies and "generalists". It has been shown that the characteristics of migrants working in elderly care in Poland influence their situation in the immigration country. It was also established that there are research differences between high-skilled and low-skilled migrants working in elderly care.

Based on the conducted research, some political implications may be formulated. Firstly, the issue of brain waste among HSMW has to be noted. A system which would make it easier to gain recognised qualifications and diplomas, and thus undertake employment in learned professions, needs to be developed. This could be implemented in a national migration policy, which Poland currently does not have, or through a systemic solution on the European Union level. However, as noted by Blain et al. (2017), even when qualifications are recognised, differences between certain groups in entering the labour market exist due to unconscious bias, in i.e. recruiting (Shinnaoui \& Narchel, 2010). The research shows that the need and self-realisation are tightly 
intermingled in migration projects, which is mainly visible in the group of highly qualified migrants with specialist education. Similar conclusions were drawn from research carried out in the Netherlands (Bruquetas-Callejo, 2019). Migrants in the elderly care sector represent a multi-embedded motivation and strategy, shaped by the home and hosts countries constrains.

Furthermore, Poland is not able to fully use the potential of HSMW, thus leading to a waste of potential: knowledge, experience - social and intellectual capital, which is especially alarming considering the sector in question - and the care sector, which, due to socio-demographic processes, will continue to grow and see increased demand for highly qualified workers. It seems necessary to use this potential, as Poland has one of the lowest share of nurses per 1000 citizens among the 28 EU countries (OECD, 2019). This shows that the workers who migrate to Poland also "suffer" from brain waste. "Very often, human capital and education acquired in the home country cannot be completely exploited as such, and the migrant faces a high depreciation in the value of her human capital" (Brezis, 2019, p. 2).

An incentive system for migrant women in the care sector needs to be developed due to the fact that Poland faces a lack of caregivers. A reliable information system about migrants, i.e. nurses, coming to Poland and working in various occupations, due to the mentioned difficulties, is lacking. Furthermore, a support system, which would facilitate a career development for migrant women, is also lacking. Particularly, since the formal barriers are the ones leading to deskilling and brain waste, they are the one decision-makers need to deal with in the first place. Research shows that some HSMW had simply assumed that they would not be able to work in their learned professions and thus undertook employment below their qualifications.

Unfortunately, the formal competencies (education) of foreigners working in the elderly care sector are not fully utilised. Moreover, high-skilled specialists declare the willingness to go back to their home country more often than generally educated highskilled and low-skilled. This means that Poland is not able to encourage them to stay and thus maintain (or increase) the level of high human capital. This may be perceived as brain, human capital or even talent waste. This results, among others, from the fact that they take up work illegally or semi-legally (e.g. they work legally elsewhere and also take care of an elderly person). Therefore, there is no issue with their competencies but rather with recognition of said competencies. It would be beneficial to introduce facilitation in employment in elderly care at the migrant management level, e.g. work permits issued for longer periods, dedicated specially for elderly caregivers. For example, Canada facilitates the arrival of those who decide to work a minimum of 2 years as live-in caregivers (Pratt, 1999). A solution facilitating the decision to legalise the caregiver's employment would be the introduction of cash benefits for families that employ a caregiver (Osterle \& Bauer, 2012). A proven solution used locally in Italy is the organisation of elderly care courses (Da Roit \& Van Bochove, 2014) and making it possible for immigrants to participate in them. Chiswick and Miller (2009a) pointed out: the lower the transferability of the skills across countries, the poorer the initial matching of educational and training qualifications to their job in the destination is.

In terms of limitations, a few were indicated through the course of the study. One such limitation is the qualitative nature of the research. As a result, the respondents may have been tried to depict themselves in a better light and to present their motives in a more positive way. Also, the fact that the interviews were conducted in Polish may 
have resulted in the loss of certain nuanced information. It was an exploratory study, the purpose of which was to recognise the phenomenon of economic immigration to the elderly care sector and migrant profile cognition. After reviewing the obtained results of the semi-structured interview, additional open questions would have been beneficial, especially to go deeper into the motives for migration, as they could influence motives for taking up employment in the care sector, the work status, as well as the women's plans. Additionally, the usage of two sampling methods (snowball and RDS), which was aimed at identifying a broader scope of respondents, may have resulted in some limitations as a thorough observation was a challenge. Also, the fact that we were not able to recruit migrants working in formal care intuitions may result in some limitations, as they may possibly have different characteristics, work status and plans.

Due to the increasing demand for foreigners in the elderly care sector, the studies should be continued to broaden the knowledge on the factors of immigrant influx into the elderly care sector, foreigner competencies, wage conditions, employment perspectives and employment services development, among others. Further research should be also carried regarding the career plans of migrant women working in the care sector. This seems to be a significant issue as the presented research indicated that the migrants with a medical background declare a higher willingness to go back to their home countries.

Funding The research was funded by the National Science Centre, Poland, as part of the Miniatura 1 competition based on agreement DEC-2017/01/X/HS4/00314.

\section{Declarations}

Conflict of Interest The authors declare no competing interests.

Open Access This article is licensed under a Creative Commons Attribution 4.0 International License, which permits use, sharing, adaptation, distribution and reproduction in any medium or format, as long as you give appropriate credit to the original author(s) and the source, provide a link to the Creative Commons licence, and indicate if changes were made. The images or other third party material in this article are included in the article's Creative Commons licence, unless indicated otherwise in a credit line to the material. If material is not included in the article's Creative Commons licence and your intended use is not permitted by statutory regulation or exceeds the permitted use, you will need to obtain permission directly from the copyright holder. To view a copy of this licence, visit http://creativecommons.org/licenses/by/4.0/.

\section{References}

Abrantes, M. (2012). Yes, but what about numbers? A quantitative contribution to the study of domestic services in Europe. International Labour Review. https://doi.org/10.1111/j.1564-913x.2012.00004.x.

Anderson, B. (2000). Doing the dirty work?: The global politics of domestic labour. Palgrave Macmillan.

Andrejuk, K. (2015). Bycie imigrantką jako zasób i jako bariera. Prowadzenie działalności gospodarczej w Polsce w narracjach imigrantek z krajów byłego ZSRR. Studia Socjologiczne, 1(216), 229-258.

Andrejuk, K. (2017). Przedsiębiorcy ukraińscy w Polsce Struktura i sprawstwo $w$ procesie osiedlenia. IFiS PAN.

Baker, M., \& Benjamin, D. (1994). The performance of immigrants in the Canadian labor market. Journal of Labor Economics, 12(3), 369-405. 
Batalova, J., \& Fix, M. (2015). Through an immigrant lens: PIAAC assessment of the competencies of adults in the United States. Migration Policy Institute. http://www.migrationpolicy.org/research/throughimmigrantlens-piaac-assessment-competencies-adults-united-states. Accessed 15 September 2019.

Bettio, F., Simonazzi, A., \& Villa, P. (2006). Change in care regimes and female migration the 'care drain' in the Mediterranean. Journal of European Social Policy, 16(3), 271-285.

Biffl, G. (2012). Labour market integration of low skilled migrants in Europe: Economic impact, Paper presented at the conference on Managing Migration and Integration: Europe and the US.

Blain, M.-J., Fortin, S., \& Alvarez, F. (2017). Professional journeys of international medical graduates in Quebec: Recognition, uphill battles, or career change. Journal of International Migration and Integration, 18(1), 223-247.

Borjas, G. J. (1991). National origin and the skills of immigrants in the postwar period, NBER Working Paper No. 3575.

Borjas, G. J. (1994). The economics of immigration. Journal of economic literature, 32(4), 1667-1717.

Börsch-Supan, A. (2013). Ageing, labour markets and well-being. Empirica, 40(3), 397-407. https://doi.org/ $10.1007 / \mathrm{s} 10663-013-9216-0$.

Boucher, A. K. (2019). How 'skill' definition affects the diversity of skilled immigration policies. Journal of Ethnic and Migration Studies, 42, 2533-2550.

Bourgeault, I. L., Atanackovic, J., \& LeBrun, J. (2011). The role of immigrant care workers in an aging society: The Canadian context and experience. Report Health Canada Research Chair in Health Human Research Policy.

Brezis, E. S. (2019). Should individuals migrate before acquiring education or after? A new model of Brain Waste vs. Brain Drain. Working Papers 2019-03, Bar-Ilan University, Department of Economics.

Brink, H. I. (1993). Validity and reliability in qualitative research. Curationis, 16(2), 35-38.

Brunello, G., Lodigiani, E., \& Rocco, L. (2017). Does low skilled immigration cause human capital polarization? Evidence from Italian Provinces. IZA DP, 11062.

Bruquetas-Callejo, M. (2019). Long-term care crisis in the Netherlands and migration of live-in care workers: Transnational trajectories, coping strategies and motivation mixes. International Migration, 51(1), 105118.

Brzozowski, J. (2008). Brain drain or brain gain? The new economics of brain drain reconsidered. The New Economics of Brain Drain Reconsidered, https://ssrn.com/abstract=1288043. Accessed 30 October 2019.

Bygnes, S., \& Erdal, M. B. (2017). Liquid migration, grounded lives: Considerations about future mobility and settlement among Polish and Spanish migrants in Norway. Journal of Ethnic and Migration Studies, 43(1), 102-118.

Cangiano, A., Shutes, I., Spencer, S., \& Leeson, G. (2009). Migrant care workers in ageing societies: Research findings in the United Kingdom: Centre on Migration, Policy and Society. University of Oxford.

Chammartin, G. (2008). Migration, gender equality and development, Paper presented at the International Conference On Gender, Migration, Ration and Development: Seizing Opportunities, Upholding Rights.

Charmaz, K. (2006). Constructing grounded theory: A practical guide through qualitative analysis. Sage.

Chiswick, B. R. (2011). Immigration: High skilled vs. low skilled labor?, https://www.econstor.eu/bitstream/ 10419/91767/1/pp28.pdf Accessed 30 October 2019

Chiswick, B. R., \& Miller, P. W. (2009a). Educational mismatch: are high-skilled immigrants really working at high-skilled jobs and the price they pay if they aren't?, IZA Discussion Paper No. 4280. https://ssrn. com/abstract $=1434614$. Accessed 28 October 2019.

Chiswick, B. R., \& Miller, P. W. (2009b). The international transferability of immigrants' human capital. Economics of Education Review, 28(2), 162-169.

Colic-Peisker, V., \& Tilbury, F. (2006). Employment niches for recent refugees: Segmented labour market in twenty-first century Australia. Journal of refugee studies, 19(2), 203-229.

Creswell, J. W., \& Miller, D. L. (2000). Determining validity in qualitative inquiry. Theory into Practice, 39(3), 124-130.

Cuban, S. (2016). The problem of skill waste among highly skilled migrant women in the UK care sector. In A. Triandafyllidou \& I. Isaakyan (Eds.), High-skill migration and recession. Migration, diasporas and citizenship. Palgrave Macmillan. https://doi.org/10.1057/9781137467119_10.

Da Roit, B., \& Van Bochove, M. (2014). Migrant workers in long-term care in the Netherlands from a comparative perspective: a literature review. Report prepared for the Centre of Expertise for Informal Care.

Docquier, F., \& Marfouk, A. (2006). International migration by education attainment, 1990-2000. In C. Ozden \& M. Schiff (Eds.), International Migration, Remittances and the Brain Drain (pp. 151-199). World Bank, Palgrave Macmillan. 
Dolińska, A. (2019). Ścieżki zawodowe wysoko wykwalifikowanych migrantek z Ukrainy i Białorusi w Polsce. Studia BAS, (4), 179-197.

England, K., \& Dyck, I. (2011). Managing the body work of home care. Sociology of Health \& Illness, 33(2), 206-219.

Eurostat. (2019). First permits by reason, https://ec.europa.eu/eurostat/web/products-datasets/-/tps00170

Ezzeddine, P. (2014). Who Cares? Ageing, Care and Migration. Lidé města, 16(2).

Ferrer, A., \& Riddell, W. C. (2008). Education, credentials, and immigrant earnings. Canadian Journal of Economics/Revue canadienne d'économique, 41(1), 186-216.

Fraser, N. (1995). Widerspenstige Praktiken. Macht, Diskurs, Geschlecht. Deutsche Zeitschrift fur Philosophie, 43, 1062-1065.

Gallo, E., \& Scrinzi, F. (2016). Outsourcing elderly care to migrant workers: the impact of gender and class on the experience of male employers. Sociology, 50(2), 366-382.

Glaser, B. G., Strauss, A. L., \& Strutzel, E. (1968). The discovery of grounded theory; strategies for qualitative research. Nursing research, 17(4), 364.

Goel, K., \& Penman, J. (2015). Employment experiences of immigrant workers in aged care in regional South Australia. Rural and Remote Health, 15(1), 14.

Gordolan, L., \& Lalani, M. (2009). Care and immigration: Migrant care workers in private households. Kalayaan report in collaboration with the Centre on Migration, Policy and Society, Kalayaan, London.

Goździak, E. (2016). Biała emigracja: Variegated mobility of Polish care workers. Social Identities, 22(1), 2643.

Groutsis, D. (2009). Recruiting migrant nurses to fill the gaps: The contribution of migrant women in the nursing care sector in Greece. Journal of International Migration and Integration, 10(1), 49-65.

Hanson, G. H. (2006). Illegal migration from Mexico to the United States. Journal of Economic Literature, 44(4), 869-924.

Harrold, L. R., Field, T. S., \& Gurwitz, J. H. (1999). Knowledge, patterns of care, and outcomes of care for generalists and specialists. Journal of General Internal Medicine, 14(8), 499-511.

Hawthorne, L. (2001). The globalisation of the nursing workforce: Barriers confronting overseas qualified nurses in Australia. Nursing inquiry, 8(4), 213-229.

Heckathorn, D. D. (1997). Respondent-driven sampling: A new approach to the study of hidden populations. Social Problems, 44(2), 174-199.

Heffner, K., Klemens, B., \& Solga, B. (2019). Challenges of regional development in the context of population ageing. Analysis based on the example of Opolskie Voivodeship. Sustainability, 11(19), 5207.

Huang, S., Thang, L. L., \& Toyota, M. (2012). Transnational mobilities for care: Rethinking the dynamics of care in Asia. Global Networks-a Journal of Transnational Affairs, 12(2), 129-134.

Hugo, G. (2009). Care worker migration, Australia and development. Population Space and Place, 15(2), 189-203.

Humphries, N., Tyrrell, E., McAleese, S., Bidwell, P., Thomas, S., Normand, C., \& Brugha, R. (2013). A cycle of brain gain, waste and drain-a qualitative study of non-EU migrant doctors in Ireland. Human Resources for Health, 11(1), 63.

Hussein, S., Manthorpe, J., \& Stevens, M. (2010). People in places: A qualitative exploration of recruitment agencies' perspectives on the employment of international social workers in the UK. British Journal of Social Work, 40(3), 1000-1016.

Iredale, R. (2016). High-skilled migration. In F. D. Bean \& S. K. Brown (Eds.), Encyclopedia of Migration (pp. 1-10). Springer Netherlands.

Kałuża-Kopias, D. (2018). Imigranci w systemie opieki nad osobami starszymi. Rynek Pracy, 3(166), 36-45.

Kindler, M., Kordasiewicz, A., \& Szulecka, M. (2016). Care needs and migration for domestic work: Ukraine-Poland. International Labour Organization. Geneva.

Knaebel, R. (2015). The invisible workers caring for the German elderly. European Trade Union Institute. https://www.etui.org/content/download/20639/169053/file/Hesamag_11_EN_26-29.pdf. Accessed 16 March 2020.

Kubiciel-Lodzińska, S. (2019). The role of immigrants in providing elderly care services for an ageing Polish Population: Complementary or substitutionary. Problemy Polityki Spolecznej, 2, 87-104.

Larsen, J. A., Allan, H. T., Bryan, K., \& Smith, P. (2005). Overseas nurses' motivations for working in the UK: globalization and life politics. Work Employment and Society, 19(2), 349-368.

Leiber, S., Matuszczyk, K., \& Rossow, V. (2019). Private labor market intermediaries in the Europeanized live-in care market between Germany and Poland: A typology. Zeitschrift für Sozialreform, 65(3), 365392.

Likupe, G. (2006). Experiences of African nurses in the UK National Health Service: A literature review. Journal of clinical nursing, 15(10), 1213-1220. 
Lo, L., Li, W., \& Yu, W. (2019). Highly-skilled migration from China and India to Canada and the United States. International Migration, 57(3), 317-333.

Lofters, A., Slater, M., Fumakia, N., \& Thulien, N. (2014). "Brain drain" and "brain waste": Experiences of international medical graduates in Ontario. Risk Management and Healthcare Policy, 7, 81.

Lovelock, K., \& Martin, G. (2016). Eldercare work, migrant care workers, affective care and subjective proximity. Ethnicity \& Health, 21(4), 379-396.

Martin, S., Lowell, B. L., Gozdziak, E. M., Bump, M., \& Breeding, M. E. (2009). The role of migrant care workers in aging societies. Report on Research Findings in the United States. Institute for the Study of International Migration, Walsh School of Foreign Service, Georgetown University, Washington DC.

Mattoo, A., Neagu, I. C., \& Ozden, C. (2008). Brain waste? Educated immigrants in the US labor market. Journal of Development Economics, 87(2), 255-269.

McGregor, J. (2007). 'Joining the BBC (British Bottom Cleaners)': Zimbabwean migrants and the UK care industry. Journal of Ethnic and Migration Studies, 33(5), 801-824.

Negin, J., Coffman, J., Connell, J., \& Short, S. (2016). Foreign-born aged care workers in Australia: A growing trend. Australasian Journal on Ageing, 35(4), E13-E17.

OECD. (2019). Health at a glance 2019: OECD indicators. OECD Publishing, Paris. https://doi.org/10.1787/ $4 \mathrm{dd} 50 \mathrm{c} 09$-en.

Okushima, M. (2010). Indonesian nurse/careworker-candidates in Japan preparing for the national examination: Background and problems. The Kanda Journal of Global and Area Studies, 1, 295-342.

O'Rourke, N., \& Tuokko, H. A. (2003). Psychometric properties of an abridged version of the Zarit Burden Interview within a representative Canadian caregiver sample. The Gerontologist, 43(1), 121-127.

Osterle, A., \& Bauer, G. (2012). Home care in Austria: The interplay of family orientation, cash-for-care and migrant care. Health \& Social Care in the Community, 20(3), 265-273.

Palenga-Möllenbeck, E. (2013). Care chains in Eastern and Central Europe: Male and female domestic work at the intersections of gender, class, and ethnicity. Journal of Immigrant \& Refugee Studies, 11(4), 364 383.

Pelzelmayer, K. (2016). Places of difference: Narratives of heart-felt warmth, ethnicisation, and female caremigrants in Swiss live-in care. Gender Place and Culture, 23(12), 1701-1712.

Pires, A. J. G. (2015). Brain drain and brain waste. Journal of Economic Development, 40(1), 1-34.

Pratt, G. (1999). From registered nurse to registered nanny: Discursive geographies of Filipina domestic workers in Vancouver, BC. Economic Geography, 75(3), 215-236.

Pylypa, J. (2013). Portrayals of global health worker migration in Canadian print news media: domestic concerns vs. global awareness. Journal of International Migration and Integration, 14(1), 81-97.

Reitz, J. G. (2001). Immigrant skill utilization in the Canadian labour market: Implications of human capital research. Journal of International Migration and Integration, 2(3), 347-378.

Rose, J., \& Johnson, C. W. (2020). Contextualizing reliability and validity in qualitative research: toward more rigorous and trustworthy qualitative social science in leisure research. Journal of Leisure Research, 51, $432-451$.

Rugolotto, S., Larotonda, A., \& van der Geest, S. (2017). How migrants keep Italian families Italian: Badanti and the private care of older people. International Journal of Migration Health and Social Care, 13(2), $185-197$.

Salami, B., Nelson, S., Hawthorne, L., Muntaner, C., \& Hall, L. M. (2014). Motivations of nurses who migrate to Canada as domestic workers. International Nursing Review, 61(4), 479-486.

Salami, B., Duggleby, W., \& Rajani, F. (2017). The perspective of employers/families and care recipients of migrant live-in caregivers: A scoping review. Health \& Social Care in the Community, 25(6), 1667-1678.

Salaris, L., \& Tedesco, N. (2019). Migration and the labour market: Ukrainian women in the Italian care sector. Journal of International Migration and Integration, 21, 1-20.

Schwiter, K., Strauss, K., \& England, K. (2018). At home with the boss: Migrant live-in caregivers, social reproduction and constrained agency in the UK, Canada, Austria and Switzerland. Transactions of the Institute of British Geographers, 43(3), 462-476.

Shinnaoui, D., \& Narchel, R. (2010). Brain gain to brain waste: Individual biases, prejudice, and discounting of migrant skills. Journal of International Migration and Integration, 11(4), 423-437.

Sobiesiak-Penszko, P. (2015). Niewidzialna sila robocza: migranci w ustugach opiekuńczych nad osobami starszymi. Fundacja Instytut Spraw Publicznych. Warszawa.

Solga, B., \& Kubiciel-Lodzinska, S. (2017). Poland: Immigration instead of emigration. Transformation of the mobility model. In Proceedings of the 30th International Business Information Management (IBIMA) Conference (pp. 797-810).

Spencer, S. (2010). The role of migrant care workers in ageing societies: Report on research findings in the United Kingdom, Ireland, Canada and the United States. IOM International Organization for Migration. 
Stilwell, B., Diallo, K., Zurn, P., Vujicic, M., Adams, O., \& Dal Poz, M. (2004). Migration of health-care workers from developing countries: strategic approaches to its management. Bulletin of the World health Organization, 82, 595-600.

Strauss, A., \& Corbin, J. (1994). Grounded theory methodology. Handbook of qualitative research, 17, 273285.

Strauss, A., \& Corbin, J. M. (1997). Grounded theory in practice. Sage.

Szeman, Z. (2012). Family strategies in Hungary: The role of undocumented migrants in eldercare. Journal of Population Ageing, 5(2), 97-118.

Szweda-Lewandowska, Z., \& Kałuża-Kopias, D. (2019). Demand for the labor of foreign caregivers from the perspective of two generations: The elderly and their family caregivers. Przedsiębiorczość $i$ Zarzadzanie, 20(3, cz. 1 Wspótczesne problemy społeczne i ekonomiczne-próba oceny i pomiaru), 79-93.

Thomas-Hope, E. (2002). Skilled labour migration from developing countries: Study on the Caribbean region: International Migration Programme. International Labour Office Geneva.

Triandafyllidou, A. (2016). Irregular migration and domestic work in Europe: who cares? In Irregular Migrant Domestic Workers in Europe (pp. 17-32). Routledge.

Van Durme, T., Macq, J., Jeanmart, C., \& Gobert, M. (2012). Tools for measuring the impact of informal caregiving of the elderly: A literature review. International Journal of Nursing Studies, 49(4), 490-504.

Van Hooren, F. (2010). When families need immigrants: The exceptional position of migrant domestic workers and care assistants in Italian immigration policy. Bulletin of Italian Politics, 2(2), 21-38.

Yagi, N., Mackey, T. K., Liang, B. A., \& Gerlt, L. (2014). Policy review: Japan-Philippines Economic Partnership Agreement (JPEPA)-analysis of a failed nurse migration policy. International Journal of Nursing Studies, 51(2), 243-250.

Yeates, N. (2010). The globalization of nurse migration: Policy issues and responses. International Labour Review, 149(4), 423-440.

Yu, K.-H. (2019). Negotiating 'otherness' as skilled migrants. Journal of Industrial Relations, 61(2), 198-224.

Publisher's Note Springer Nature remains neutral with regard to jurisdictional claims in published maps and institutional affiliations. 